\title{
Inorganic phytoplankton nutrients in the Wadden Sea areas off Schleswig-Holstein. II. Dissolved ortho-phosphate and reactive silicate with comments on the zooplankton
}

\author{
Peter Martens \\ Biologische Anstalt Helgoland (Wadden Sea Institute); D-W-2282 List/Sylt, \\ Federal Republic of Germany
}

\begin{abstract}
In the summer months of $1984,1986,1987$ and 1988 , several stations off the west coast of Schleswig-Holstein were investigated with regard to the situation of ortho-phosphate, reactive silicate and mesozooplankton. An increase in phosphate was observed, whereas an increase in silicate could only be found in the areas influenced by the River Eider. Polychaete larvae show a decreasing tendency in the summer months; this is thought to be influenced by water temperature.
\end{abstract}

\section{INTRODUCTION}

For more than 13 years, planktological parameters such as zooplankton, phytoplankton and phytoplankton-nutrients have been measured by the Biologische Anstalt Helgoland at different stations in the Northern Wadden Sea of Sylt. This is the most northern Wadden Sea area of Schleswig-Holstein. It is separated from the southern areas of the German Wadden Sea by the Hindenburg Dam. For this reason, the results of these longterm investigations cannot be extrapolated to the southern Wadden Sea areas which are influenced by the rivers Elbe and Eider to a much greater extent. In 1984, a series of investigations was started at different locations along the west coast of SchleswigHolstein to measure trends and gradients in space in the eutrophication of the Wadden Sea areas. As shown by Radach \& Berg (1986) for the German Bight, an increase in nutrients was observed in the Northern Wadden Sea of Sylt (Martens, 1989b) as well as in the southern adjacent areas for dissolved nitrogen (Martens 1989a). This paper tries to throw light on the subject of ortho-phosphate and reactive silicate as well as on some members of the zooplankton community in the Wadden Sea areas of Schleswig-Holstein.

\section{MATERIALS AND METHODS}

In the summer months (June to August) of 1984, 1986, 1987 and 1988, investigations were carried out at several stations on the west coast of Schleswig-Holstein (Fig. 1) with respect to different hydrographical parameters. The following parameters were analysed:

(1) Temperature $\left( \pm 0.05^{\circ} \mathrm{C}\right.$; reversing thermometer)

(C) Biologische Anstalt Helgoland, Hamburg 
(2) Salinity ( $\pm 0.001 \mathrm{~S}$; Salinometer model Guildline 8400A)

(3) Chlorophyll-a (UNESCO standard method)

(4) Mesozooplankton (>76 $\mu \mathrm{m})$

(5) $\mathrm{pH}( \pm 0.01 \mathrm{pH})$

(6) Dissolved oxygen (Winkler method)

(7) Phytoplankton-nutrients $\left(\mathrm{PO}_{4}, \mathrm{Si}, \mathrm{NH}_{4}, \mathrm{NO}_{2}, \mathrm{NO}_{3}\right)$ (Graßhoff, 1976)

(8) Seston-dry weight

(9) Particulate organic carbon (POC) and particulate organic nitrogen (PON)

The meteorological station List (DWD) provided weather data. Quarterly mean values of rainfall during this period of investigation were computed on the basis of daily rainfall measurements. For details, see Martens (1989a).

The hydrographical samples were taken with transparent-plastic-Nansen(TPN)water samplers (Hydrobios system) at the surface. Samples were taken in turbulently mixed tidal gullies where no stable stratification occurs (Hickel, 1975; - Martens, unpubl. data). Mesozooplankton samples were taken with buckets, 351 water being sieved through $76 \mu \mathrm{m}$ gauze. The samples were determined to the species level under the microscope in the laboratory and the number of individuals per litre transformed to dry weight values by means of empirical factors (Hillebrandt, 1972; Martens, 1976).

\section{RESUITS}

Figure 1 shows the position of the stations on the west coast of Schleswig-Holstein. The low draft of the R.V. Mya $(0.75 \mathrm{~m})$ made these near-shore stations possible. Figures 2-4 show the phosphate and silicate content at the different stations.

Up to Tonne SH8, a relatively low silicate content can be found, with decreasing concentrations in the past years. In the area where the influence of the River Eider begins (Fig. 4), a rising tendency can be seen with highest concentrations at the outflow of the River Eider itself (Eider-Sperrwerk).

Figure 5 shows the concentrations of phosphate and silicate at three stations in the River Eider. As could be expected, high concentrations of micronutrients contrasting with those of the marine environment could be found.

Phosphate gives a different picture compared to silicate. There is no decreasing tendency even in the most northern stations (Fig. 2), a slight increase can be found at all stations visited, with very high concentrations near the outflow of the rivers Eider and Elbe.

The zooplankton dry weight values (Figs 6 to 8) show a marked reduction at some of the stations (e.g. Eider Sperrwerk or Cuxhaven) where a high percentage is formed by polychaete larvae. These larvae have shown a decreasing tendency during the summers of recent years. This is not true in the case of the holoplankton e.g. calanoid copepods. Figure 9 gives the development of this animal group from 1984 to 1988 at the stations Lister Hafen and Cuxhaven. They are taken as being representative of the rest of the stations visited. 


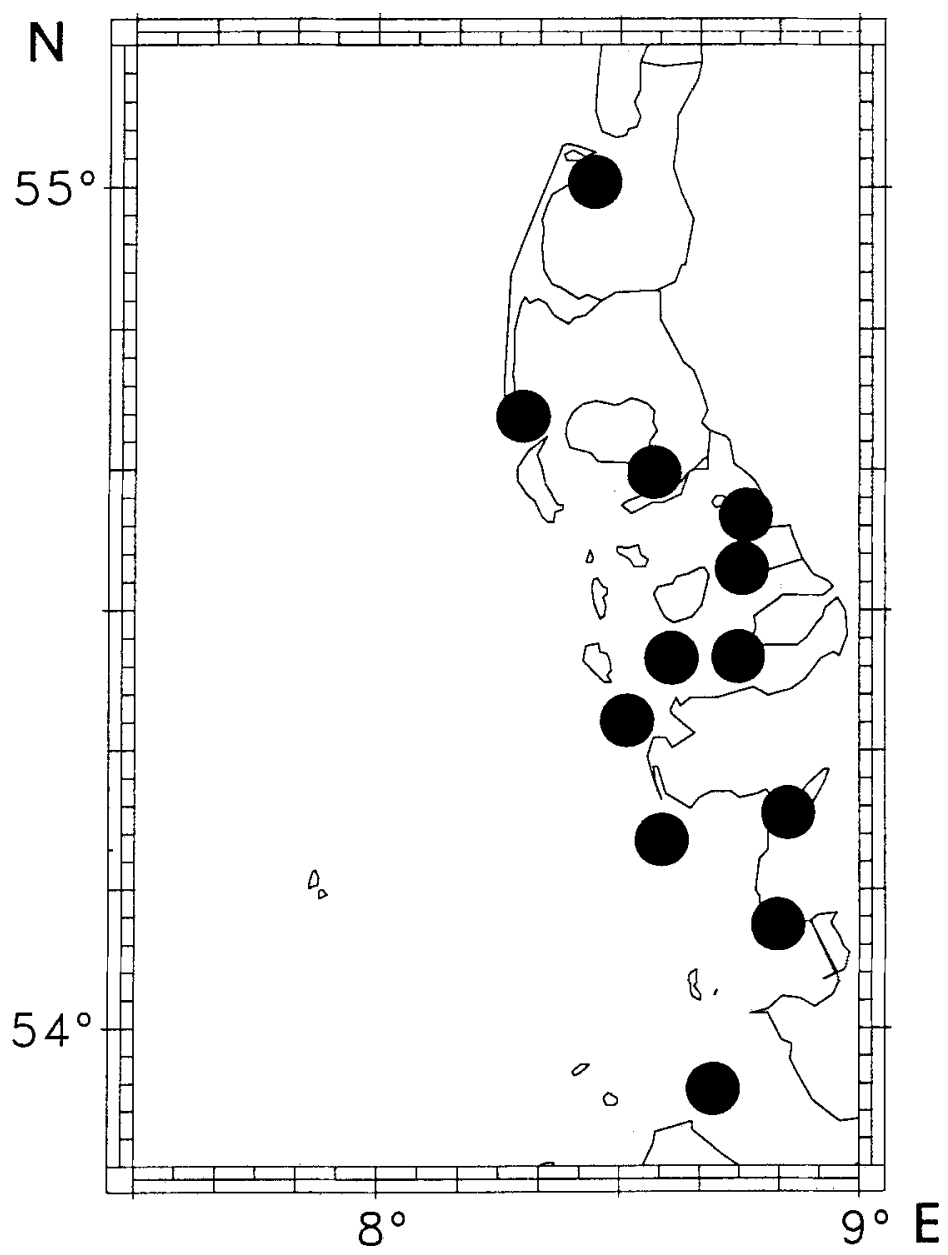

Fig. 1. Position of the stations investigated off the west coast of Schleswig-Holstein (from north to south): Lister Hafen (List harbour), Amrum-Tief (Amrum deep), Föhrer Ley, Hamburger Hallig, Pellworm Hafen (Pellworm harbour), Tonne (buoy) Hever Grün 41, Tonne (buoy) Hever Rot 22, Tonne (buoy) SH8-SH9, Eider-Sperrwerk (Eider estuary), Tonne (buoy) Eider Rot 10, Büsum Hafen (Büsum harbour) and Cuxhaven

\section{DISCUSSION}

\section{Nutrients}

As shown earlier (Martens, 1989a), an increase in rainfall during the years 1984-1988 led to an increased outflow of the River Eider (Fig. 10) which caused an increase in dissolved inorganic nitrogen compounds. Now it has been shown that the same holds true for the micronutrient silicate at least.

As has been shown by Hagmeier (1978), Lucht \& Gillbricht (1978), Hickel (1989) and Martens (1989b), the micronutrient phosphate has an increasing tendency in the German 

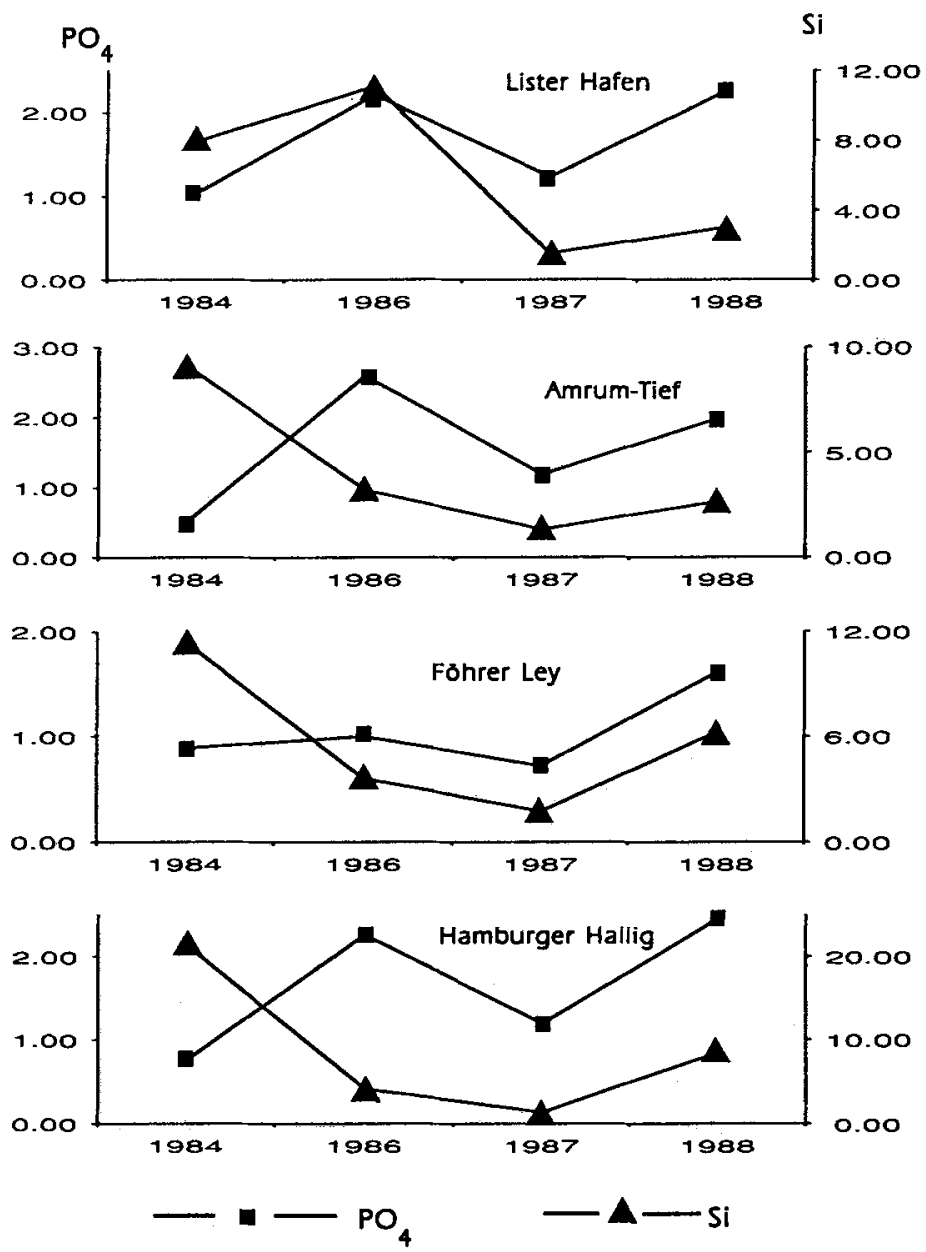

Fig. 2. Ortho-phosphate and reactive silicate concentration $\left(\mu \mathrm{mol} \cdot \mathrm{dm}^{-3}\right)$ during the summer of the years 1984 and 1986-1988 at the stations Lister Hafen, Amrum-Tief, Föhrer Ley and Hamburger Hallig (see Fig. 1) (surface values)

Bight, mainly influenced by the River Elbe, and the northern Wadden Sea areas of Schleswig-Holstein. So an increase in phosphate which showed up during this investigation would only be natural as the daily water exchange between the German Bight and the Wadden Sea areas in question is high. Figure 4 shows the influence of the River Elbe on the phosphate concentration in the German Bight, as shown earlier by Brockmann \& Eberlein (1986).

This is not the case with silicate. Radach \& Berg (1986) have shown a decreasing tendency for silicate in the German Bight as is the case in the more northern stations visited during this cruise. South of the peninsula Eiderstedt we find a marked influence by the River Eider with its relatively high concentrations of silicate compared to the marine environment. These concentrations of about $120 \mu \mathrm{mol} \mathrm{l}^{-1} \mathrm{Si}$ are normal values for fresh waters (Hütter, 1988) and are often found in the rivers of Schleswig-Holstein 

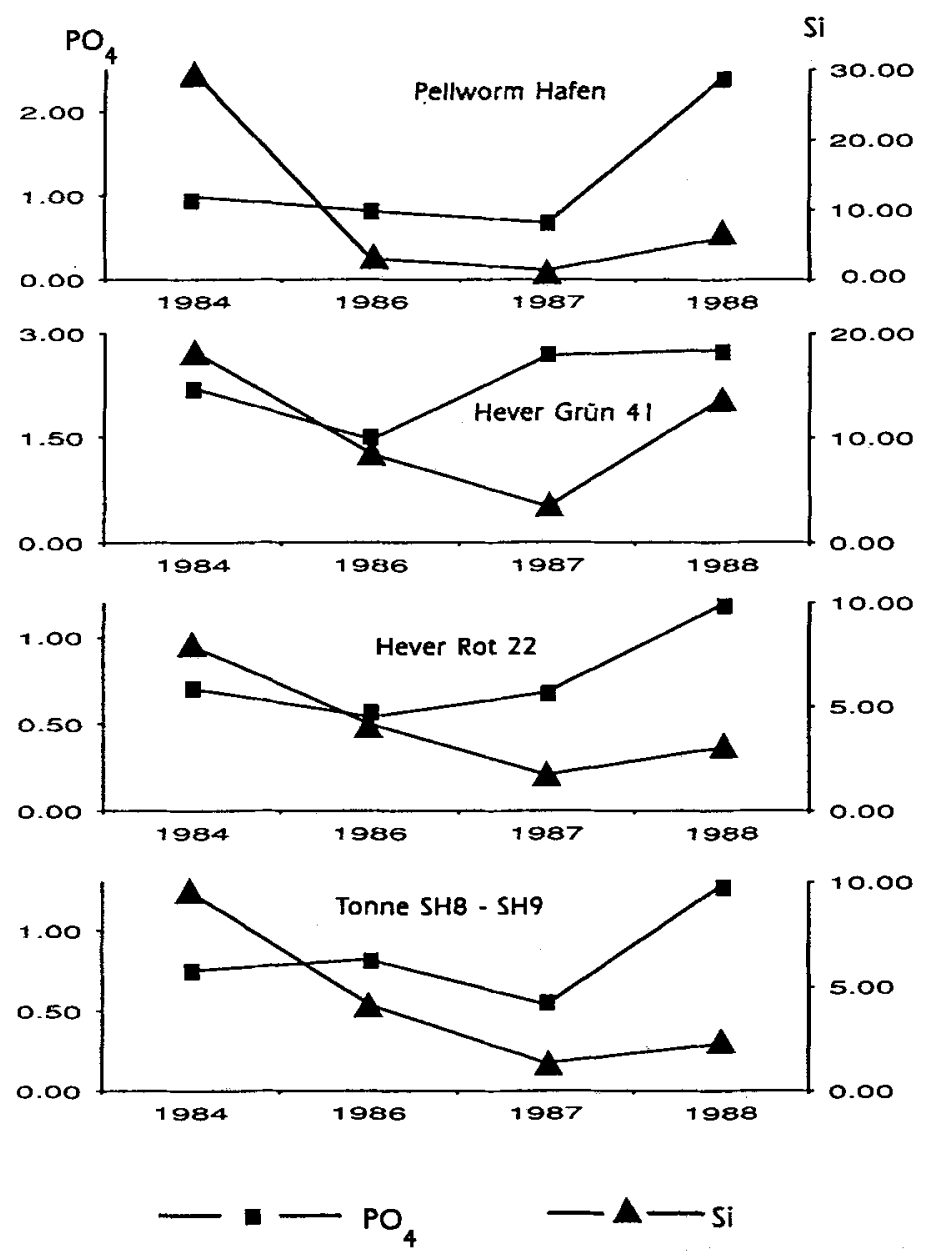

Fig. 3. Ortho-phosphate and reactive silicate concentration $\left(\mu \mathrm{mol} \cdot \mathrm{dm}^{-3}\right)$ during the summer of the years 1984 and 1986-1988 at the stations Pellworm Hafen, Hever Grün 41, Hever Rot 22 and Tonne SH8-SH9 (see Fig. 1) (surface values)

(Sommer, pers. comm.). The heavier rainfalls during the past years lead to an increased river runoff (Martens, 1989a). In contrast to the high nitrogen input into the Wadden Sea by the River Eider, this silicate input is most likely not a case of man-made pollution but a natural effect. The River Eider and its confluent Treene drain the whole geest areas, the sandy regions in the middle of Schleswig-Holstein.

\section{Zooplankton}

Unfortunately, we do not have any longer time series of the zooplankton and its environment at stations along the southern part of the Schleswig-Holstein west coast. The only location visited regularly over several years is the Northern Wadden Sea of Sylt. 

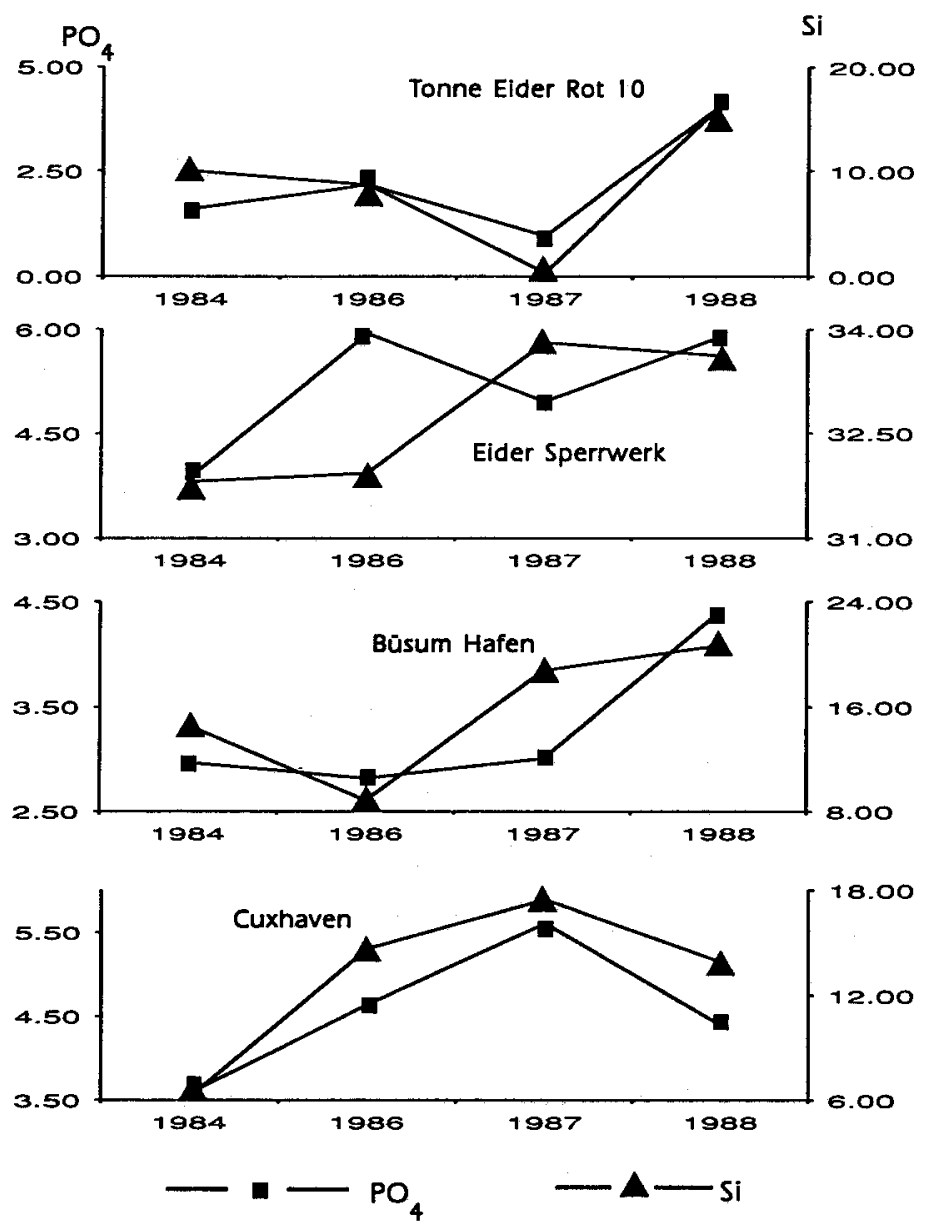

Fig. 4. Ortho-phosphate and reactive silicate concentration $\left(\mu \mathrm{mol} \cdot \mathrm{dm}^{-3}\right)$ during the summer of the years 1984 and 1986-1988 at the stations Tonne Eider Rot 10, Eider-Sperrwerk, Büsum Hafen and Cuxhaven (see Fig. 1) (surface values)

Figure 11 shows that in 1986, as in previous years, polychaete larvae showed up in great quantities at the beginning of May shortly after a marked increase in temperature. As Rasmussen (1973) has shown for the animals of the Isefjord, this is typical for spionid larvae, which form the majority of the polychaete larvae at the stations visited.

The water temperature in 1988 showed a different development in time compared to the water temperature in 1986 . In February, the temperature was already $5^{\circ} \mathrm{C}$. This led to the effect that there was a show of polychaete larvae during the whole spring, and not just a unique "bloom" of larvae, the total number of larvae produced being about the same as in earlier years (Martens, unpubl. data).

Acknowledgements. Sincere thanks are due to C. Reineke and the crew of the F.K. Mya for technical support even at times when conditions were unfavourable. The staff of the meteorological station List, Deutscher Wetterdienst, supports us regularly with meteorological data. 


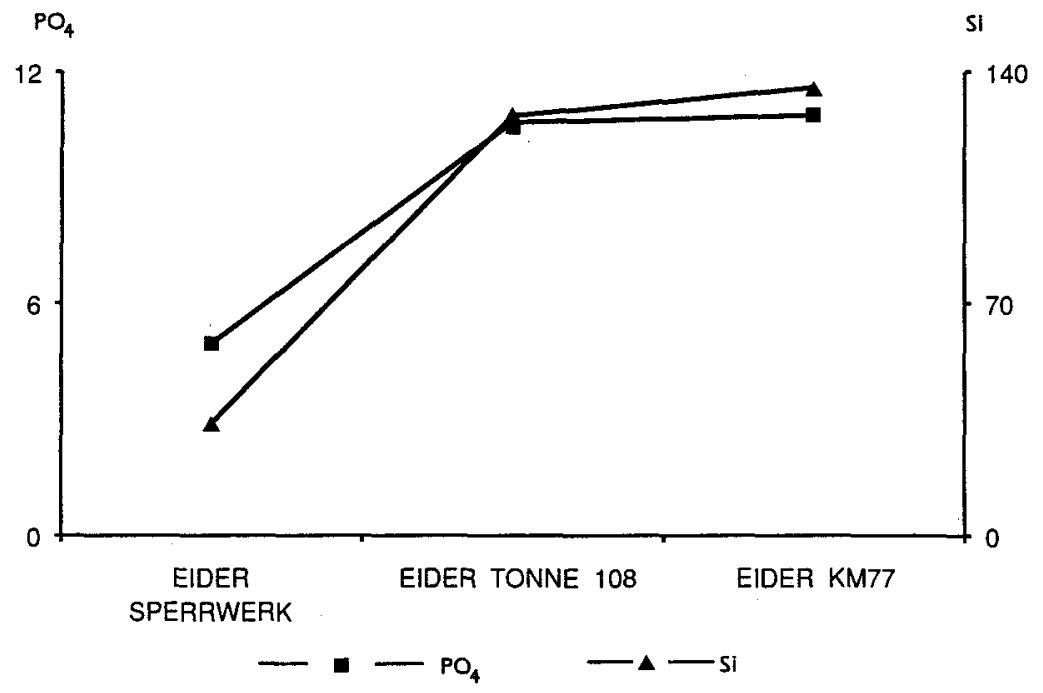

Fig 5. Concentrations of ortho-phosphate and reactive silicate at three stations in the River Eider (surface values) $\left(\mu \mathrm{mol} \cdot \mathrm{dm}^{-3}\right)$ during a cruise in August 1987 

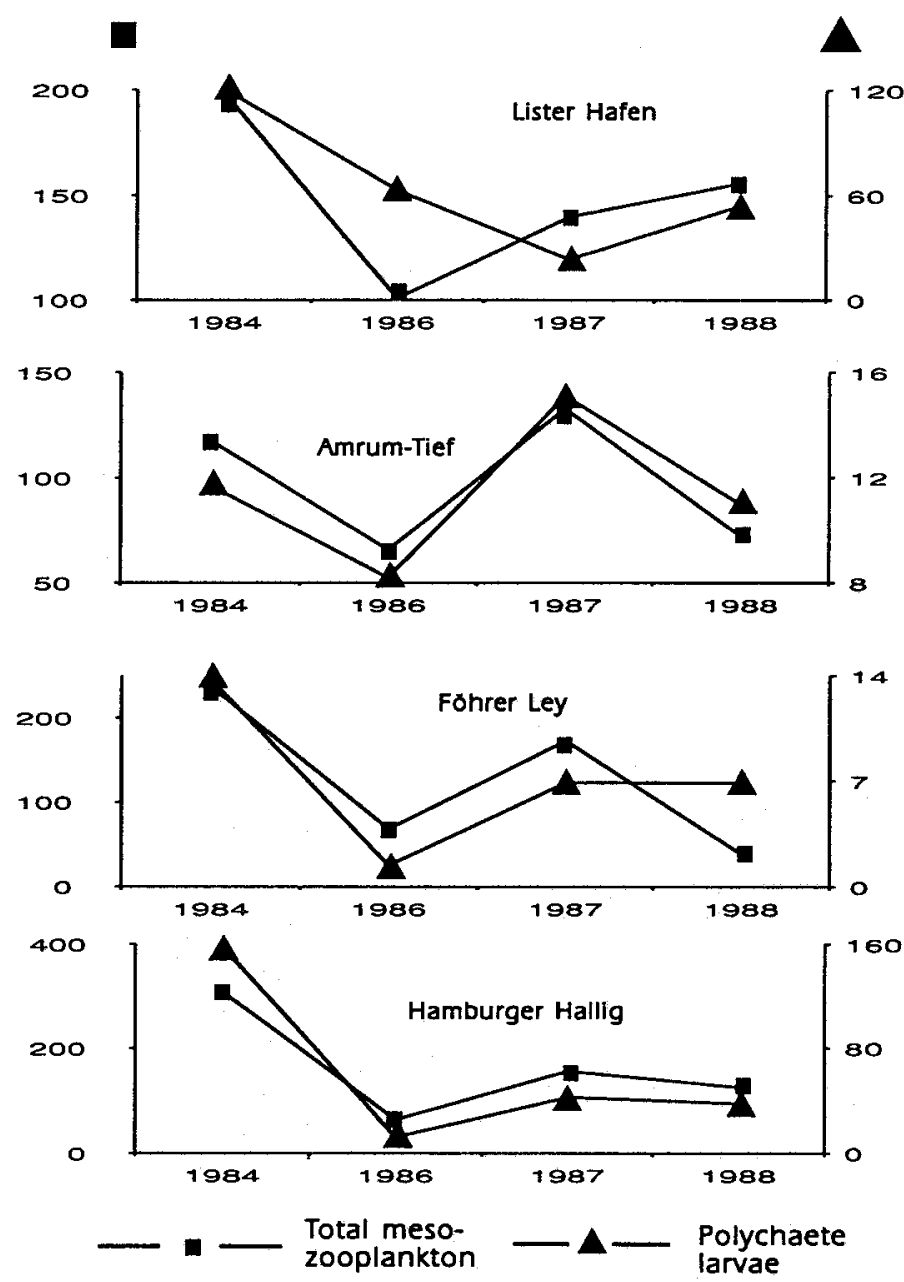

Fig. 6. Amount of mesozooplankton dry weight at the stations Lister Hafen, Amrum-Tief, Föhrer Ley and Hamburger Hallig during the summer of the years 1984 and 1986-1988 (surface values) ( $\mu \mathrm{g}$ dry weight $\cdot \mathrm{dm}^{-3}$ ) 

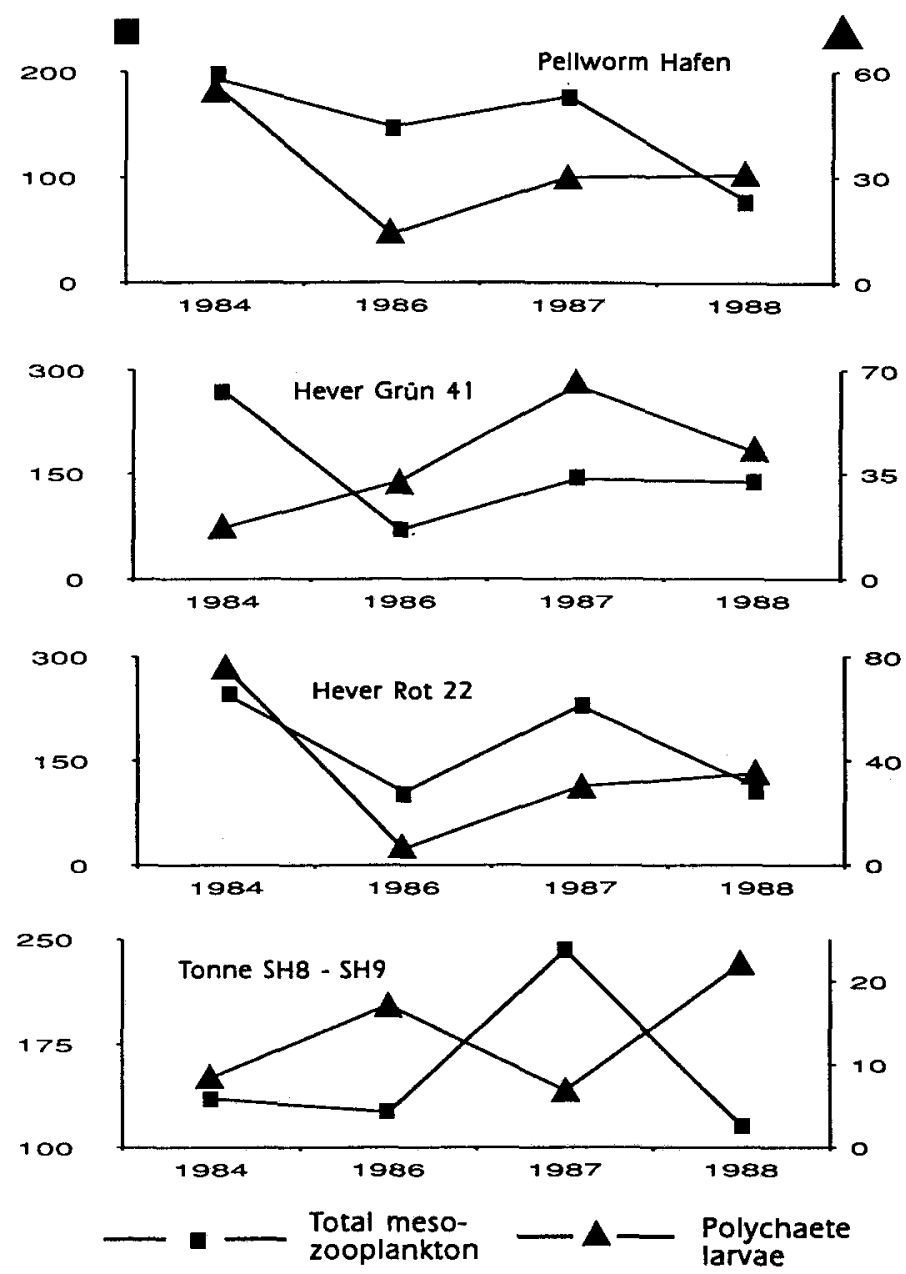

Fig. 7. Amount of mesozooplankton dry weight at the stations Pellworm Hafen, Hever Grün 41, Hever Rot 22 and Tonne SH8-SH9 during the summer of the years 1984 and 1986-1988 (surface values) ( $\mu \mathrm{g}$ dry weight $\cdot \mathrm{dm}^{-3}$ ) 

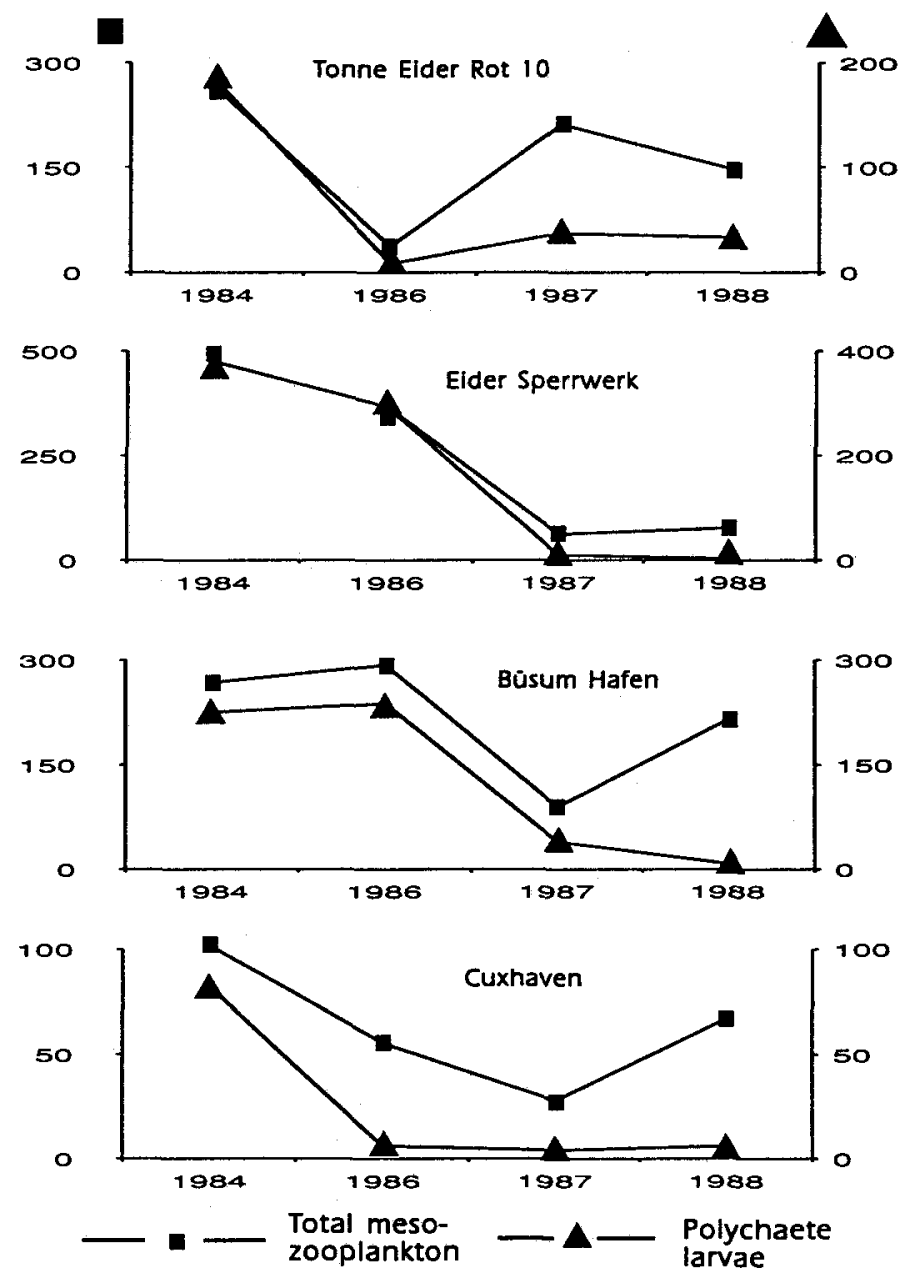

Fig. 8. Amount of mesozooplankton dry weight at the stations Tonne Eider Rot 10, Eider-Sperrwerk, Büsum Hafen and Cuxhaven during the summer of the years 1984 and 1986-1988 (surface values) $\left(\mu \mathrm{g}\right.$ dry weight $\left.\cdot \mathrm{dm}^{-3}\right)$ 
$\mu \mathrm{gdm}-3$
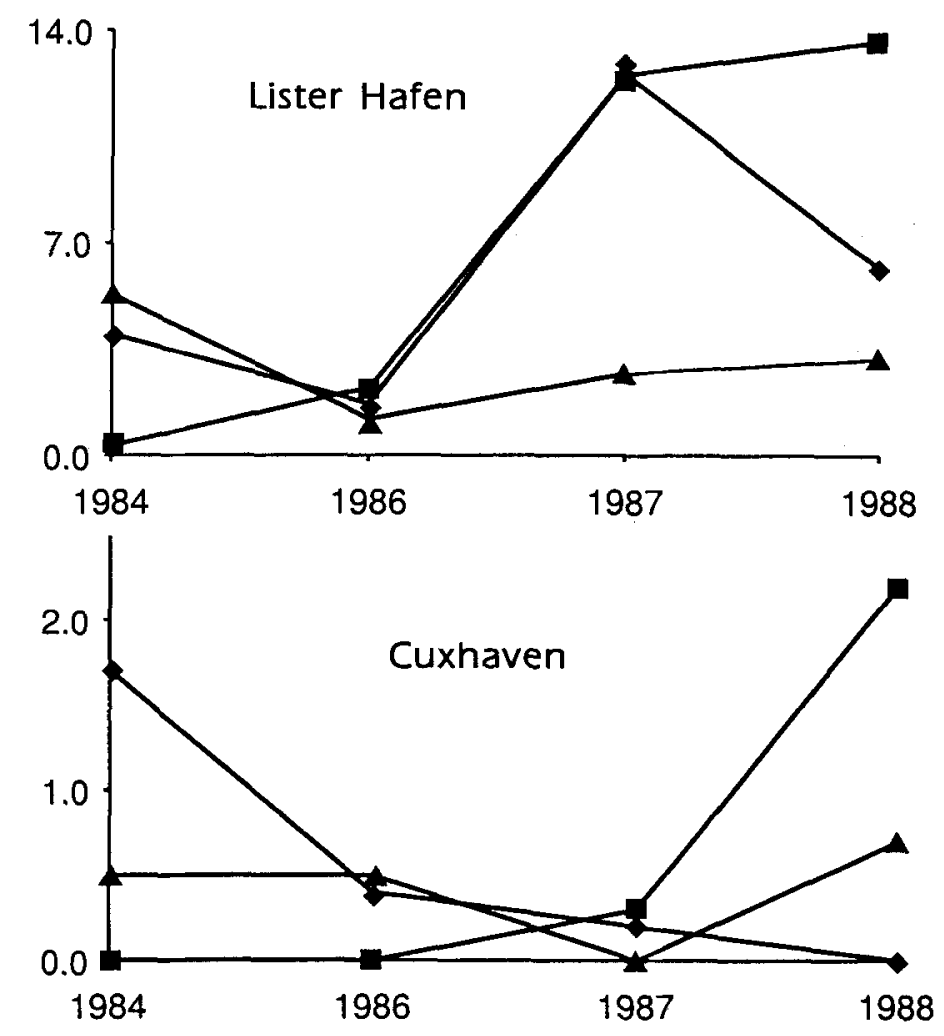

- Acartia sp. a Centropages sp. A Temora sp.

Fig. 9. Concentration of Acartia sp., Centropages hamatus and Temora longicornis ( $\mu \mathrm{g}$ dry weight $\cdot \mathrm{dm}^{-3}$ ) at stations Lister Hafen and Cuxhaven in the summer of the years 1984 and 1986-1988 (surface values) 


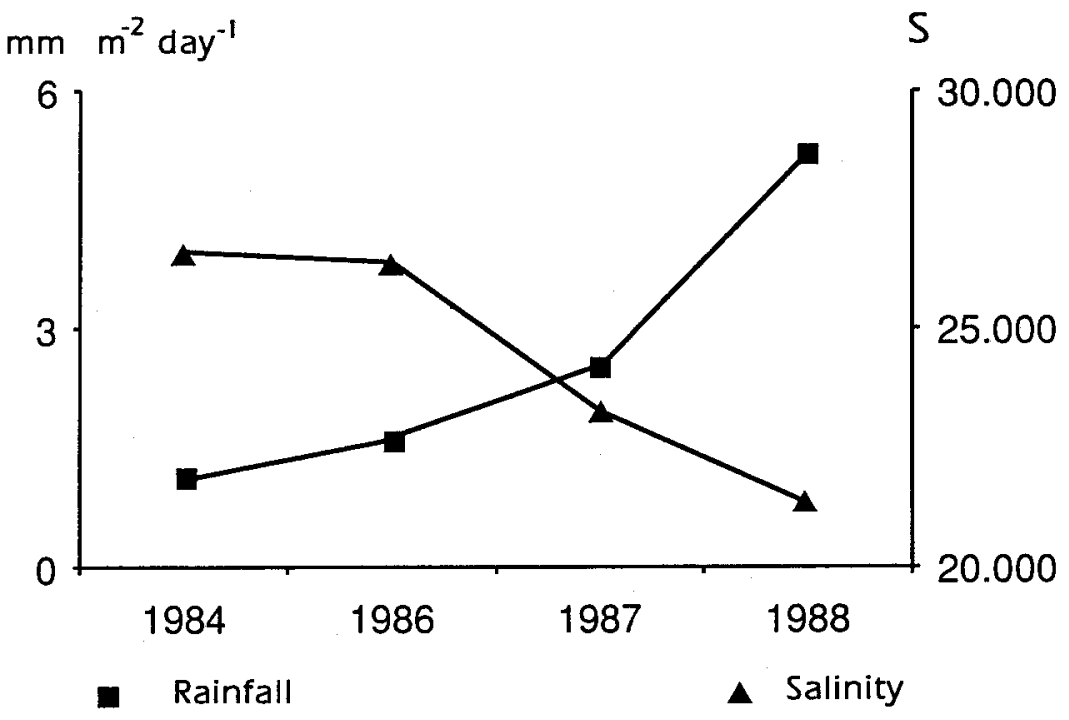

Fig. 10. Mean values of rainfall $\left(\mathrm{mm} \cdot \mathrm{m}^{-2} \cdot\right.$ day $\left.^{-1}\right)$ in List (meteorological station) during the periods of investigation and salinity (S) at station Eider-Sperrwerk

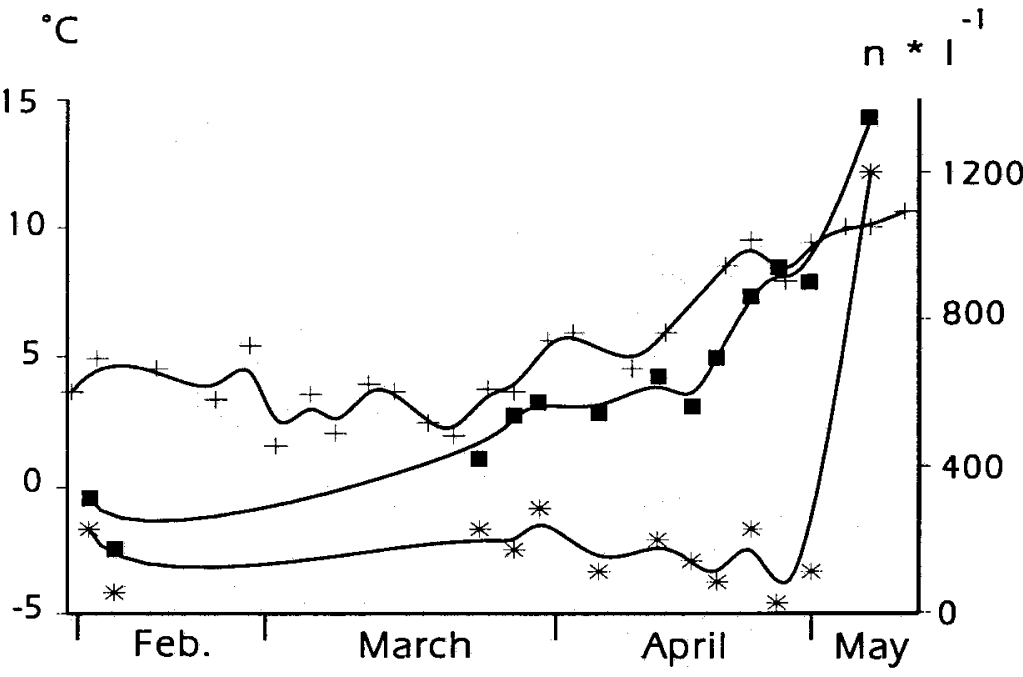

Fig. 11. Temperature $\left({ }^{\circ} \mathrm{C}\right)$ and spionid larvae $\left(n \cdot \mathrm{dm}^{-3}\right)$ at station Lister Hafen in February/May 1986 (temperature and larvae) and 1988 (temperature); (polynomial smoothing); $\mathbf{\square}=$ Water temperature in $1986 ;+=$ Water temperature in $1988 ; *$ * Polychaete larvae in 1986 


\section{LITERATURE CITED}

Brockmann, U. H. \& Eberlein, K., 1986. River input of nutrients into the German Bight. In: The role of freshwater outflow in coastal marine ecosystems. Ed: by S. Skreslet. Springer, Berlin, 231-240.

Graßhoff, K., 1976. Methods of seawater analysis. Verl. Chemie, Weinheim, $317 \mathrm{pp}$.

Hagmeier, E., 1978. Variations in phytoplankton near Helgoland. - Rapp. P. v. Réun. Cons. int. Explor. Mer 172, 361-363.

Hickel, W., 1975. The mesozooplankton of the Wadden Sea of Sylt (North Sea). - Helgoländer Meeresunters. 27, 254-262.

Hickel, W., 1989. Inorganic micronutrients in relation to phytoplankton and the eutrophication in the Wadden Sea of Sylt (German Bight, North Sea). In: Proceedings of the twenty-first European Marine Biology Symposium. Ed. by R. Z. Klekowski, E. Styczyńska-Jurewicz \& L. Falkowski. Institute of Oceanology, Polish Academy of Sciences, Wroclaw, 309-318.

Hillebrandt, M., 1972. Untersuchungen über die qualitative und quantitative Zusammensetzung des Zooplanktons in der Kieler Bucht während der Jahre 1966-1968. Diss., Univ. Kiel, 138 pp.

Hütter, L. A., 1988. Wasser und Wasseruntersuchung. Diesterweg, Frankfurt, 443 pp.

Lucht, F. \& Gillbricht, M., 1978. Long-term observations on nutrient contents near Helgoland in relation to nutrient input of the river Elbe. - Rapp. P. v. Réun. Cons. int. Explor. Mer 172, 358-360.

Martens, P., 1976. Die planktischen Sekundär- und Tertiärproduzenten im Flachwasserökosystem der westlichen Ostsee. - Kieler Meeresforsch. (Sonderh.) 3, 60-71.

Martens, P., 1989a. Inorganic phytoplankton nutrients in the Wadden Sea areas off SchleswigHolstein. I. Dissolved inorganic nitrogen. - Helgoländer Meeresunters. 43, 77-85.

Martens, P., 1989b. On trends in the nutrient-concentration in the northern Wadden Sea of Sylt. Helgoländer Meeresunters. 43, 489-499.

Radach, G. \& Berg, J., 1986. Trends in den Konzentrationen der Nährstoffe und des Phytoplanktons in der Helgoländer Bucht (Helgoland Reede Daten). - Ber. Biol. Anst. Helgoland 2, 1-63.

Rasmussen, E., 1973. Systematics and ecology of the Isefjord marine fauna (Denmark). - Ophelia 11, $1-495$. 